in the U.K. or who pay in sterling with cheques drawn on a U.K. bank. A notice regarding Irish subscriptions appears with the Call for Subscription on page 189.

Apart from symposia and courses, there are also several "Doctors' Sports Events" taking place, and we have just read a notice in General Practitioner relating to the World Medical Games, together with a symposium on Sports Medicine, to take place in Cannes from June 7th-14th, 1980. Enquiries should be sent to Dr. David Delvin, 'General Practitioner', Haymarket Publishing, 76 Dean Street, London W1. The approximate cost will be $\$ 350$, including air fare, accommodation and registration for the games.

Two other news items that have been noted are the foundation of a Society of Orthopaedic Medicine, that should interest many of our members dealing with soft tissue diseases and trauma; enquiries to 206 Albany Street, LONDON NW1 (01-388-2226), and a report in the Sunday Express of December 23rd and no doubt in other papers in a more lurid style, concerning a lady member of BASM who was called to examine a concussed rugby player in the dressing room, unaware that the rest of the team were changing. The committee of the home team resented their visitors' remedial gymnast, but as women doctors and therapists are playing an important part in 'front line sports medicine", the obvious answer to complaints is to do what our association has been advocating for many years; - make proper facilities for a first aid and treatment room, even if part of the bar has to be taken off to make room for an equally essential facility.

The first issue of Volume 14, 1980 will be devoted largely to the publication of the proceedings of a two day symposium held at Exeter. Work on transcribing from tape and editing the communications is well advanced, and it is hoped to publish at the end of February or early March. More information should also be available for our future programme. Meanwhile the annual reports, accounts and other notices relating to the Annual General Meeting should be circulated in March.

7th January, 1980

H.E. ROBSON

\title{
OBITUARY
}

\section{Dr.P. J. R. NICHOLS}

Philip Nichols, whose tragic death was recently reported, was one of the leading figures in rehabilitation in the United Kingdom. Apart from being Consultant Adviser to the D.H.S.S. he was Director of Mary Marlborough Lodge and as such made his greatest and most lasting contribution to the art in the development of treatment methods and aids for the severely handicapped.

In recent years he had turned his attention to a critical study of the methods of treatment of soft-tissue injuries which brought him into the field of Sports Medicine. He was briefly a member of the BASM and it must always be regretted that he was denied the time and opportunity to realise his awakening interest in the management of sports injuries. We shall, alas, never know the valuable contribution he could have made in this demanding field.

J. G. P. Williams 